\title{
The Role of Real Wages, Productivity, and Fiscal Policy in Germany's Great Depression, 1928-37
}

\author{
Jonas D. M. Fisher and Andreas Hornstein
}

The Great Depression was a period of extraordinary turbulence in modern German economic history. Starting in 1928, output declined within four years by more than 30 percent relative to trend and then almost completely recovered within the following five years. Employment, consumption, and investment also fell dramatically during the Depression. After the trough of the Depression in 1932, employment and investment recovered along with output, but consumption stagnated.

We study the Depression in Germany from the perspective of the neoclassical growth model. In particular, we study how changes in real wages, productivity, and fiscal policy affected the performance of the economy. We find that these three factors largely account for the macroeconomic dynamics of the German Depression.

Furthermore, we find that changes in real wages were the most important of these three factors in accounting for the Depression in Germany. Real wages increased by 10 percent relative to trend while labor productivity declined. In the recovery period, real wages and labor productivity returned to trend. We argue that a large part of the real wage movement was due to distortions in the labor market of the German economy. In the growth model, we treat the observed real wage changes as exogenous, and employment is determined by the demand for labor. Holding the other two factors fixed, real wage changes account for somewhat more than two-thirds of the decline in output and all of the decline in employment during the Depression. They also account for the later recovery in employment and some of the stagnation in consumption, but little of the recovery in output. This suggests that labor market distortions were important causes of the Depression in Germany.

Changes in productivity also were important factors of the Depression. Total factor productivity (TFP) declined by 16 percent relative to trend and 
then returned to trend in the recovery period. We treat these productivity movements as exogenous country-specific changes of the efficiency of production. Holding the other two factors - real wages and fiscal policy-fixed, productivity changes account for somewhat less than two-thirds of the decline in output and two-fifths of the decline in employment during the Depression. During the recovery phase, the subsequent return of productivity to trend predicts too strong a recovery.

Changes in fiscal policy also had a noticeable effect on the Depression, but that effect is significantly smaller than the effect of real wage and productivity changes. Under restrictive fiscal policy, effective tax rates increased by onefifth, and government purchases declined by about 16 percent relative to trend. In the recovery phase, fiscal policy became expansive: government purchases almost tripled from their 1932 value, while tax rates remained at their depression levels. We model the unprecedented increase of government purchases during the recovery phase as unanticipated by the private sector. Holding the other two factors fixed, fiscal policy accounts for a quarter of the decline in output and employment during the Depression. On the other hand, fiscal policy predicts too rapid a recovery for output and employment, but it does account for some of the stagnation of consumption in the recovery phase.

Finally, we consider the effects of a simultaneous change in real wages, productivity, and fiscal policy. We find that the combination of all three factors can account for the qualitative features of the Depression, but it exaggerates the quantitative magnitude of the fluctuations.

Our analysis abstracts from a number of alternative explanations for the Depression: monetary policy, a malfunctioning financial system, the reparation payments imposed by the Versailles Treaty after World War I, and international trade. Given the relative success of our simple framework, we find this abstraction justified. Furthermore, in the next section we point out some problems associated with the alternative explanations.

The remainder of the paper is organized as follows. First, we describe the behavior of various macroeconomic variables of the German economy during the period 1928-37. We also describe the German labor market and fiscal policy of that time period, which motivates our focus on real wages, productivity, and fiscal policy. We then describe the model we used to interpret the data. Then we discuss our results on the impact of real wages, productivity, and fiscal policy.

\section{The German Economy, 1928-37}

In this section we discuss factors of the economic history and underlying data of the 1928-37 period in Germany that motivate our focus on real wages, productivity, and fiscal policy. Our discussion of the data emphasizes the be- 
havior of German per capita output and other variables describing the supply and demand for that output, the situation in the labor market, and the stance of fiscal policy. The sources for our data are described in the appendix.

Most of the series we discuss have a trend, and we display their behavior after we have removed that trend. As a standard first step, we normalize all series for the scale effects of population size when appropriate, that is, we express them as per capita series. There are various ways to remove any remaining trend, and we pick a method that is appropriate for the study of balanced-growth paths in the neoclassical growth model. In particular, on a balanced-growth path with constant government spending shares and tax rates, output, consumption, investment, government purchases, real wages, and labor productivity all grow at a common rate. Therefore, we detrend the per capita series of these variables with the gross national product (GNP) per capita trend growth rate. ${ }^{1}$ We calculate the trend growth rate from pre-World War I GNP data. The growth rate of GNP per capita for the period 1901-13 is 1.87 percent. This growth rate is very close to the average growth rate of output per capita for all of Germany from 1904 to 1980, which is 1.9 percent, where we use GNP before 1945 and gross domestic product (GDP) after 1945. Finally, hours worked will have no trend if income and substitution effects cancel. We therefore do not detrend per capita hours worked.

\section{Decline and Recovery}

The German economic expansion of the 1920s ended in 1928 when GNP per capita reached its peak. This expansion was followed by the Depression, during which GNP per capita declined by about 30 percent; this decline lasted for four years. We observe an uninterrupted recovery from 1933 to 1937. A comparison with the United States provides some perspective on the extent to which the Depression affected Germany. In Figure 1 we display the path of detrended GNP per capita in Germany and the United States for the years following their respective pre-Depression peaks and the two years preceding the peaks. First note that the U.S. expansion in the 1920 s reached its peak in 1929, one year after Germany. Second, the magnitude and the duration of the output decline in the Depression were almost the same in the two economies. Third, the recovery from the Depression was different in the two countries: Germany's recovery lasted for five years until 1937, whereas the U.S. recovery phase stalled after about three years in 1936. We end our study of the German economy in 1937 because from 1938 on, the data on the German economy are not reliable, for two reasons. First, since Germany annexed Austria in 1938, separate official statistics on the two countries are no longer available. ${ }^{2}$ Second, World War II began in 1939, and the data for the German war economy are even less reliable. 
Figure 1. Output during Depression in Germany and United States

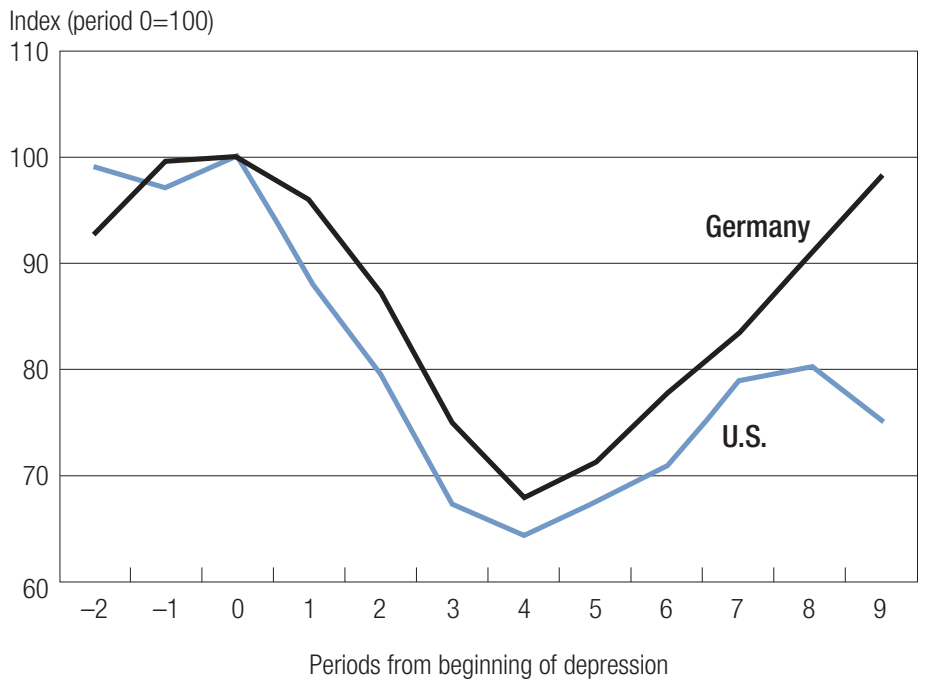

Figure 2. German and U.S. output (1901-93)

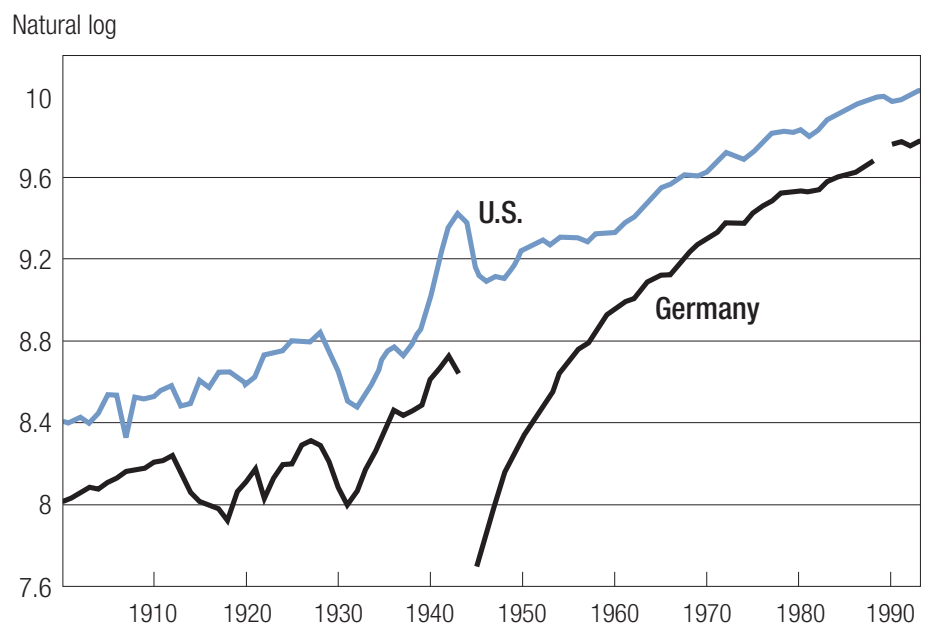

Although the magnitude of the Depression appeared to be similar in Germany and the United States, it did play a different role in Germany's interwar period. This can be seen in Figure 2, which displays German and U.S. per capita output from 1901 to 1993 . We can see that the Great Depression repre- 
sented a singular event in the twentieth century for the United States. But for the twentieth-century German economy, economic activity was below trend for the complete interwar period, and not only for the years of the Depression. Over the duration of World War I, German per capita GNP declined by 30 percent, and output never really recovered its pre-World War I levels. Even in 1928, when the German economy was at its peak, output was still below the trend growth level. ${ }^{3}$

\section{Production}

The Depression represented an unusually large decline in economic activity. In Table 1, we display the behavior of output, capital and labor inputs, and productivity measures for the time period 1928-37. In that table and the tables that follow, we use boldface to indicate the year in which output reached its trough.

The large fall of production during the Depression was accompanied by a similarly large decline of employment: in 1932 employment was 26 percent below its 1928 level. ${ }^{4}$ Since output declined more than employment, labor productivity declined in the Depression: in 1932 it was 9 percent below its 1928 value. However, labor productivity recovered as sharply as it declined and within four years was back to its 1928 levels. Not only did labor pro-

\section{Table 1. Production and the real wage, 1928-37}

\begin{tabular}{lrrrrrr}
\hline Year & Output & $\begin{array}{r}\text { Capital } \\
\text { stock }\end{array}$ & \multicolumn{1}{c}{ Labor } & $\begin{array}{c}\text { Labor } \\
\text { productivity }\end{array}$ & \multicolumn{1}{c}{ TFP } & Real wage \\
\hline 1928 & 100.0 & 100.0 & 100.0 & 100.0 & 100.0 & 100.0 \\
1929 & 95.9 & 98.9 & 99.3 & 96.6 & 96.7 & 104.6 \\
1930 & 87.1 & 97.4 & 93.3 & 93.4 & 92.4 & 109.8 \\
1931 & 74.9 & 95.2 & 82.5 & 90.7 & 87.5 & 111.3 \\
1932 & $\mathbf{6 7 . 8}$ & $\mathbf{9 2 . 8}$ & $\mathbf{7 4 . 1}$ & $\mathbf{9 1 . 5}$ & $\mathbf{8 6 . 5}$ & 109.5 \\
1933 & 71.1 & 90.6 & 76.2 & 93.3 & 89.4 & 106.8 \\
1934 & 77.7 & 88.8 & 84.2 & 92.2 & 90.9 & 104.2 \\
1935 & 83.4 & 87.3 & 84.5 & 98.7 & 98.2 & 103.2 \\
1936 & 90.8 & 86.2 & 87.5 & 103.7 & 104.4 & 102.2 \\
1937 & 98.2 & 85.5 & 89.8 & 109.3 & 111.0 & 100.6 \\
\hline
\end{tabular}

Note: Output is real GNP from Ritschl 2002b. The construction of the capital stock series is described in the appendix. Labor is total hours worked from Lölhöffel 1974. Labor productivity is output per hour worked. The calculation of TFP is described in the subsection on production. Real wages are nominal wages from Lölhöffel 1974 deflated with the price index for finished manufactured goods from Bry 1960. All variables except the real wage are per capita. Output, capital, labor productivity, TFP, and real wages are detrended with the per capita real GNP trend growth rate. All series are normalized to 100 in 1928. Boldface indicates the year of the trough in real per capita GNP. 
ductivity decline, which could be attributed to a declining capital stock, but TFP declined even more than labor productivity. ${ }^{5}$ This happened even though investment collapsed and the capital stock declined, since the capital-labor ratio still increased. Accounting for the effects of a higher capital-labor ratio means that TFP declined by 13 percent during the Depression. We again observe a very fast recovery within four years after 1932 .

Aggregate real wages are shown in the last column of Table $1 .{ }^{6}$ In contrast to productivity, real wages were strongly countercyclical in the $1928-37$ period. In the Depression, real wages increased by 11 percent, returning slowly to their 1928 levels. Given the steep decline of productivity in the Depression, the increase of real wages during this time is puzzling.

Real wages increase for two reasons. First, in the early phase of the Depression, nominal wages increased, and they started to decline slowly only later on. In Figure 3 we display nominal hourly labor cost by industry, 1928-37. We can see that for almost all industries, nominal wages started to decline only from 1930 on, that is, two years into the Depression. Second, in 1930 the German economy deflated substantially. In Table 2 we can see the extent of price deflation in the Germany economy. From 1928 to 1933, the price level in Germany fell between 20 and 30 percent, depending on the price index used, and most of this decline took place from $1930 \mathrm{on}$. With these dynamics of nominal wages and prices, detrended real wages increased substantially from 1928 to 1931.

It is reasonable to assume that money played some role in the Depression, since the price decline contributed so much to the increase in real wages.

Figure 3. Co-movement of nominal wages (1928-37)

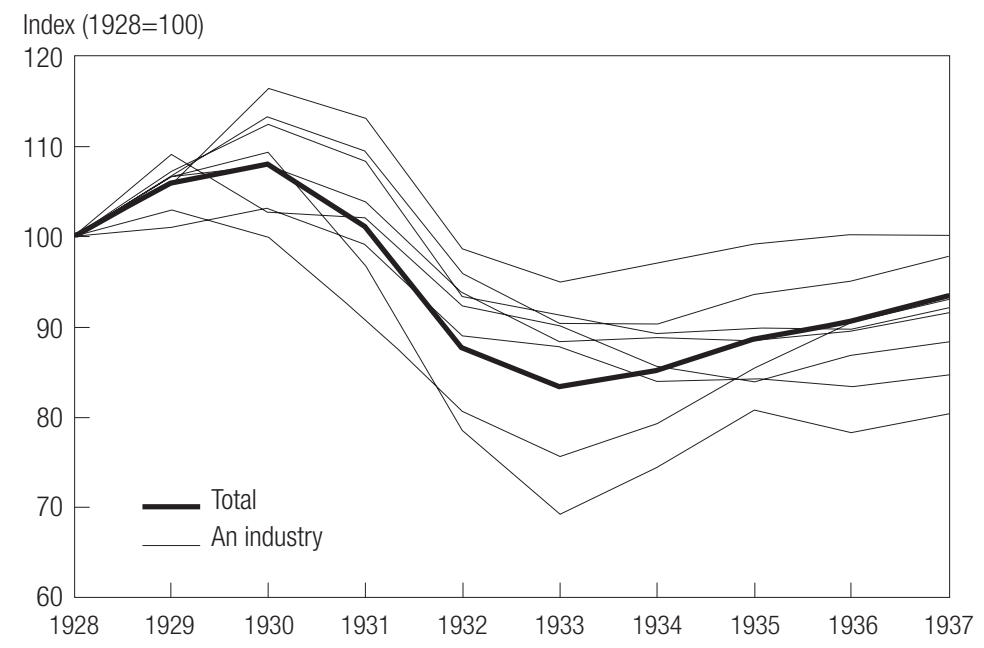


Table 2. Prices and the money supply, 1928-37

\begin{tabular}{lcccr}
\hline \multicolumn{5}{c}{ Price index } \\
\cline { 2 - 5 } Year & Finished goods & Cost of living & GNP deflator & M1 \\
\hline 1928 & 100.0 & 100.0 & 100.0 & 100.0 \\
1929 & 99.3 & 101.3 & 101.8 & 101.5 \\
1930 & 94.7 & 97.4 & 101.3 & 95.2 \\
1931 & 85.9 & 89.5 & 95.5 & 80.7 \\
1932 & 74.3 & 79.6 & 84.3 & 72.8 \\
1933 & 71.1 & 77.6 & 80.5 & 74.2 \\
1934 & 73.0 & 79.6 & 80.9 & 80.0 \\
1935 & 75.3 & 80.9 & 80.6 & 89.4 \\
1936 & 76.4 & 81.6 & 80.3 & 96.6 \\
1937 & 78.6 & 82.2 & 81.0 & 104.2 \\
\hline
\end{tabular}

Note: The cost of living price index and the wholesale price index for finished manu-factured goods are from Bry 1960; the implicit GNP deflator is from Ritschl 2002b. M1 is currency in the nonbanking sector plus demand and time deposits from Deutsche Bundesbank 1976. All time series are normalized to 100 in 1928, but not detrended. Boldface indicates the year of the trough in real per capita GNP.

A large body of literature contends that monetary policy - in particular, a malfunctioning gold standard - played a major role in the Depression; see the work of Eichengreen (1992). In the mid-1920s most industrial countries returned to the gold standard as the monetary system. In Germany, the gold standard was reintroduced in 1924 as part of the Dawes Plan revision of reparations payments. After the DANAT Bank failed in July 1931, Germany experienced a banking crisis by midyear. This crisis in the financial sector came while the Depression was already well under way, and it may have contributed to the Depression or simply reflected the stresses imposed on the economy by the Depression. In response to the banking crisis, the Reichsbank introduced foreign exchange controls and effectively abandoned the gold standard (James 1986).

To the extent that monetary policy affects the economy, we would expect that this is reflected in the behavior of M1 (see Table 2). Indeed, we can see that nondetrended M1 and prices followed a similar trajectory, at least in the Depression. We might note, however, that the money stock lagged output by about a year. This lag in the money stock relative to output is one justification to focus our analysis on real factors, at least initially. In this paper we therefore investigate an alternative view of the time path of real wages, namely that it reflects changes in the underlying structure of the labor market. ${ }^{7}$ 


\section{Wage Determination in the Labor Market}

Wage setting in the German economy of the 1920s was, to a large extent, the outcome of collective bargaining between unions and employers and/or employer federations, and the government exercised a considerable degree of control. ${ }^{8}$ The Stinnes-Legien agreement (November 15, 1918) and subsequent legislation established the collective bargaining system in the post-World War I German economy. ${ }^{9}$ Collective bargaining determines wages and working conditions, and in case of conflict, an arbitration committee determines the contract. From October 1923 on, arbitration committees were under the supervision of the Reich Labor Ministry, and the chairman of the committee, usually a Ministry bureaucrat, could impose binding arbitration (decree from December 1923). The Reich Labor Ministry could make arbitration legally binding, which made subsequent strikes and lockouts illegal. In general, the Reich Labor Ministry and its arbitrators were seen as sympathetic to the wage demands of the unions.

At the time of the Depression, a substantial fraction of the labor force was subject to some form of collective bargaining. ${ }^{10}$ Two-thirds of bluecollar workers, who made up about half of the labor force, were covered. In addition, about 30 percent of white-collar employees were union members, and white-collar employees made up about 17 percent of the labor force. From this we conclude that about 40 percent of the labor force, most of it in manufacturing, mining, and building crafts, were probably subject to some form of collective bargaining.

After the hyperinflation of 1923, unions used the collective bargaining system to negotiate wage increases, which made up for real wage losses experienced in the hyperinflation. In 1927 the Reich government raised public sector pay by 33 percent, in response to which the unions bargained for comparable wage increases because they anticipated a renewal of inflation. After 1928, large unions were faced with competition from radicalized independent unions with links to the German Communist Party, and they initially refused wage cuts during the Depression (James 1986, 216). In an attempt to deal with budgetary problems created by the Depression, the government reduced civil service pay by 20 percent in 1931. In the belief that wages in general were too high, the government tried, at the end of 1931, to reduce private sector wages by decree to their January 1927 level.

In 1933, after Hitler took power, the unions were dissolved and became part of the German Labor Front, an umbrella organization that included all labor market participants. This organization promoted the political and economic pacification of the labor market. Initially, the Nazi regime supported minimum wages (National Labor Law, January 1934). After the recovery was under way, the Nazi regime then tried to limit wage increases by setting maximum wages and restricting labor mobility. ${ }^{11}$ 


\section{Expenditures}

We now turn to the behavior of the expenditure components of German GNP: government spending on goods and services, private consumption and investment, and exports and imports. Panel $A$ of Table 3 displays these series in levels, and panel $B$ of Table 3 displays them as shares of real GNP.

In response to a worsening budget situation in the Depression, the government followed an austerity policy. This policy is usually associated with the name of Heinrich Brüning, the chancellor of the German Reich in the years 1930-32. On the expenditure side, the austerity policy involved reductions of government spending, and most of these cuts affected government invest-

Table 3. GNP expenditure components, 1928-37

\begin{tabular}{|c|c|c|c|c|c|}
\hline \multicolumn{6}{|c|}{ Panel A: Detrended levels, $1928=100$} \\
\hline Year & G & $\mathrm{C}$ & $x$ & Ex & Im \\
\hline 1928 & 100.0 & 100.0 & 100.0 & 100.0 & 100.0 \\
\hline 1929 & 105.7 & 95.6 & 80.6 & 110.1 & 101.7 \\
\hline 1930 & 93.5 & 93.6 & 41.6 & 101.1 & 92.9 \\
\hline 1931 & 83.1 & 86.5 & 5.4 & 90.0 & 84.5 \\
\hline 1932 & 86.0 & 80.2 & 11.1 & 63.3 & 79.0 \\
\hline 1933 & 101.2 & 76.1 & 36.4 & 55.5 & 69.1 \\
\hline 1934 & 136.4 & 76.5 & 55.2 & 51.1 & 70.2 \\
\hline 1935 & 148.2 & 77.3 & 66.9 & 52.7 & 62.3 \\
\hline 1936 & 163.7 & 79.9 & 80.2 & 61.8 & 62.4 \\
\hline 1937 & 205.7 & 81.6 & 90.8 & 70.7 & 73.8 \\
\hline \multicolumn{6}{|c|}{ Panel B: Shares in GNP } \\
\hline Year & G & $C$ & $x$ & Ex & Im \\
\hline 1928 & 0.12 & 0.75 & 0.15 & 0.17 & 0.20 \\
\hline 1929 & 0.14 & 0.75 & 0.13 & 0.20 & 0.21 \\
\hline 1930 & 0.13 & 0.81 & 0.07 & 0.20 & 0.22 \\
\hline 1931 & 0.14 & 0.87 & 0.01 & 0.21 & 0.23 \\
\hline 1932 & 0.16 & 0.89 & 0.02 & 0.16 & 0.24 \\
\hline 1933 & 0.18 & 0.81 & 0.08 & 0.13 & 0.20 \\
\hline 1934 & 0.22 & 0.74 & 0.11 & 0.11 & 0.18 \\
\hline 1935 & 0.22 & 0.70 & 0.12 & 0.11 & 0.15 \\
\hline 1936 & 0.22 & 0.66 & 0.13 & 0.12 & 0.14 \\
\hline 1937 & 0.26 & 0.63 & 0.14 & 0.12 & 0.15 \\
\hline
\end{tabular}

Note: Government purchases of goods and services $(\mathrm{G})$, private consumption $(\mathrm{C})$, private investment $(X)$, exports (Ex), and imports (Im) are from Ritschl 2002b and are described in the appendix. All variables are real per capita, detrended with the per capita real GNP trend growth rate, and levels are normalized to 100 in 1928. Boldface indicates the year of the trough in real per capita GNP. 
ment spending. But cuts in investment spending have only a limited effect on overall government spending, since government spending on goods and services is essentially determined by the behavior of government consumption, which represents about 80 percent of total government spending on goods and services. For example, by 1932 public spending on construction had been cut in half, but overall government spending was down only 10 percent because government consumption was almost back to trend. ${ }^{12}$

The biggest reductions in government spending took place in 1931-32. These expenditure cuts included the previously mentioned reductions of civil service pay: from December 1930 to December 1931, civil service pay was cut by about 20 percent. These pay cuts applied not only to the Reich but also to state and municipal employees. But even in these years, the share of government spending in GNP was stable or increasing. In 1933 Hitler came to power, and during the recovery from 1933 on, government spending increased in only five years to more than twice its 1928 level. This expansion of the budget was driven mainly by military expenditures. By 1937, government claimed more than a quarter of total production. It is not surprising, then, that contemporaries view German fiscal policy as an example of demand management policies, especially the fiscal expansion of the Hitler regime.

Private consumption and investment declined more during the Depression than their government counterparts did. Consumption never regained its 1928 level during the Nazi recovery, but investment made a complete recovery. At the depths of the Depression, private consumption had been reduced to three-fourths of its 1928 peak, and private investment had collapsed. In 1931 business investment was about 5 percent of its 1928 peak. Most of this decline was due to an enormous inventory reduction, but in 1932 even fixed investment was less than one-third of its 1928 peak. ${ }^{13}$ From then on, private investment staged a full recovery, but private consumption stagnated at its trough levels. This pattern reflected the policies of the Nazi government that allowed a restoration of productive capacity through investment but diverted resources from private consumption toward government consumption. As a result, in 1937 only 63 percent of total production went to private consumption, as opposed to 75 percent in 1928.

Foreign trade does not appear to have been an important contributing factor to either the decline or the recovery. During the early years of the Depression, exports continued to grow faster than trend, and only in 1932 did they fall below trend. Trade volume reached its peak only in 1931, when the sum of real exports and imports was about 45 percent of real GNP. On the other hand, it is unlikely that the expansion after 1933 could have been driven by trade, since after 1932, the trade volume started to decline to about 25 percent of real GNP. 


\section{Fiscal Policy}

Since it plays an important part in our analysis, we now provide more detail on fiscal policy. ${ }^{14}$ Government played a bigger role in the German economy after World War I relative to the prewar economy, at least in terms of the share of government spending and taxation in GNP. The main budgetary expenditure components of the central government, the Reich, were social spending (about 40 percent, excluding education) and agricultural subsidies. The main tax sources were a corporation tax, income tax, and a turnover (sales) tax. In the previous section we outlined the behavior of real government spending on goods and services (see Table 3). In the following discussion, we also refer to the time paths of implicit tax rates and the GNP share of government spending and transfers displayed in Table 4. The income tax measure is the sum of nominal direct taxes and contributions to social security and unemployment insurance divided by nominal factor income. The sales tax measure is the ratio of indirect taxes minus subsidies to GNP less indirect taxes minus subsidies. ${ }^{15}$ All data are taken from the work of Ritschl (2002b).

For most of the post-World War I period, German governments ran deficits, and they had problems financing these deficits. The Depression made it even more difficult to finance any deficits, and as previously discussed, the Brüning cabinet implemented an austerity policy, reducing purchases of goods and services. It also cut subsidies by 25 percent, but the share of government

Table 4. Fiscal policy, 1928-37

\begin{tabular}{|c|c|c|c|c|c|c|}
\hline \multirow[b]{2}{*}{ Year } & \multicolumn{3}{|c|}{$\begin{array}{l}\text { Government spending } \\
\text { as a fraction of GNP }\end{array}$} & \multicolumn{3}{|c|}{ Implicit tax rates } \\
\hline & Total & $G$ & $\mathrm{Tr}$ & $\tau^{i}$ & $\tau^{e}$ & $\tau$ \\
\hline 1928 & 0.23 & 0.13 & 0.11 & 0.12 & 0.13 & 0.21 \\
\hline 1929 & 0.25 & 0.14 & 0.12 & 0.12 & 0.13 & 0.22 \\
\hline 1930 & 0.27 & 0.13 & 0.14 & 0.13 & 0.13 & 0.23 \\
\hline 1931 & 0.29 & 0.13 & 0.16 & 0.14 & 0.15 & 0.25 \\
\hline 1932 & 0.33 & 0.15 & 0.18 & 0.13 & 0.17 & 0.26 \\
\hline 1933 & 0.33 & 0.17 & 0.16 & 0.13 & 0.16 & 0.25 \\
\hline 1934 & 0.34 & 0.20 & 0.14 & 0.13 & 0.15 & 0.24 \\
\hline 1935 & 0.33 & 0.21 & 0.12 & 0.13 & 0.15 & 0.24 \\
\hline 1936 & 0.32 & 0.21 & 0.11 & 0.14 & 0.14 & 0.25 \\
\hline 1937 & 0.35 & 0.25 & 0.10 & 0.16 & 0.14 & 0.26 \\
\hline
\end{tabular}

Note: Nominal purchases of goods and services (G), transfer payments (Tr), and GNP are from Ritschl 2002b. We have not included reparations and interest on government debt. The calculation of the implicit income tax rate $\tau^{i}$ and sales tax rate $\tau^{e}$ is described in the text, and the effective tax rate $\tau$ is based on (1). Boldface indicates the year of the trough in real per capita GNP. 
transfers in GNP continued to increase (see Table 4). In order to balance the budget of the unemployment insurance system, benefits were cut and contribution rates were raised. Finally, in order to raise revenues, a variety of income surtaxes were introduced, but the basic income and corporation tax structure was not changed. The cabinet also increased a variety of indirect taxes. Because the Reich reduced transfers to the states, the states and municipalities started to increase local taxes. Our calculated implicit tax rates in Table 4 reflect the higher income and sales taxes. ${ }^{16}$

In January 1933, Hitler was appointed Reich chancellor. In terms of economic policy, the Hitler regime did not represent a radical break with past conservative policies, at least not until $1936 .{ }^{17}$ The Hitler government maintained the tax rate increases of the Brüning government, as reflected in Table 4. It also started to implement some work programs that were discussed in the Brüning government. These work programs remained limited because of continued concern about the inflationary impact of large deficit-financed work creation programs. As part of a takeover of the state and local governments, the Reich government enforced balanced budgets for state and municipal governments, and the overall government budget deficit as a fraction of GNP did not exceed 5 percent until 1935. Some of the higher investment spending by the Reich then just replaced reduced state and municipal investment, and large infrastructure programs, such as autobahn construction, never made up a large share of government spending. In fact, total public spending on roads (including autobahns) never much exceeded 6 percent of total government spending (see Ritschl 2002a). On the other hand, rearmament quickly became an important part of the government budget. Before 1935, military spending represented 20 percent of the Reich budget; in 1935 that share was already 50 percent, and the share then increased to 80 percent by 1938 (see Ritschl 2002a). This increase of government spending is reflected in Tables 3 and 4 .

\section{Analytical Framework}

In this section we describe our framework for analyzing the Depression in Germany over the period 1928-37. The basis for our analysis is a standard neoclassical growth model with government spending and distortionary taxes. To quantify the roles of productivity, fiscal policy, and real wages, we study perfect foresight equilibria in this model under different assumptions. The experiments described in the following section (under "Findings") share several common assumptions that we outline in this section. In particular, we describe how we parameterize the model and describe the assumptions that define the baseline case that serves as a reference point for the experiments. 


\section{The Model}

The representative household has preferences over consumption, $c_{t}$, and leisure, $1-n_{t}, \sum_{t=0}^{\infty} \beta^{t}\left\{\log c_{t}+\eta \log \left(1-n_{t}\right)\right\}$, with $\eta>0,0<\beta<1$. Population grows by the factor $\mu \geq 1$, and all variables are in per capita terms. The household constraints are

$$
\begin{aligned}
\left(1+\tau_{t}^{e}\right)\left(c_{t}+x_{t}\right) & =\left(1-\tau_{t}^{i}\right)\left[w_{t} n_{t}+r_{t} k_{t}\right]+s_{t} \\
\mu k_{t+1} & =(1-\delta) k_{t}+x_{t}, \\
c_{t}, x_{t}, n_{t}, k_{t} & \geq 0 \text { and } k_{0} \text { given. }
\end{aligned}
$$

Here $x_{t}$ denotes purchases of investment goods, $k_{t}$ is the household's beginning of period stock of capital, $w_{t}$ is the wage, $r_{t}$ is the rental rate on capital, $\tau_{t}^{i}$ is an income tax rate, $\tau_{t}^{e}$ is an expenditure tax rate, and $s_{t}$ is a lump-sum transfer. Capital depreciates at the rate $0<\delta<1$. Capital income and labor income are taxed at the same rate, and capital income is taxed gross of depreciation. The effective income tax rate is then defined by

(1) $1-\tau_{t}=\frac{\left(1-\tau_{t}^{i}\right)}{\left(1+\tau_{t}^{e}\right)}$.

The homogeneous output good, $y_{t}$, is produced by competitive firms with a Cobb-Douglas production function $y_{t}=A_{t} k_{t}^{\alpha}\left(\gamma^{t} n_{t}\right)^{1-\alpha}$, where $0<\alpha<1$. Variations in the exogenous variable $A_{t}$ are due to policy changes that affect the efficiency with which inputs are used to produce output and $\gamma \geq 1$ reflects the growth of usable knowledge.

Government spending $g_{t}$ does not provide any utility and is not productive. The government budget constraint is balanced period by period: $g_{t}+s_{t}=\tau_{t}^{i}\left[w_{t} n_{t}+r_{t} k_{t}\right]+\tau_{t}^{e}\left(c_{t}+x_{t}\right)$. Finally, the aggregate resource constraint is $y_{t}=c_{t}+x_{t}+g_{t}$.

A time period represents a year, and we set the time discount factor at $\beta=$ 1/1.04. We choose $\eta$ such that the representative agent supplies one-third of the time endowment in the labor market. In a competitive equilibrium, the Cobb-Douglas coefficient $1-\alpha$ is equal to the labor income share in GNP. For the time period 1925-37 the labor income share varies between 0.73 and 0.78 , and we choose the mean over this period, that is, $1-\alpha=$ 0.75 . We calculate the annual depreciation rate $\delta$ at $0.0122 .{ }^{18}$ We choose the long-run growth factor of productivity as $\gamma=1.0187$, the annual trend growth factor of per capita GNP in Germany, 1901-13. We also allow for population growth at $\mu=1.007$, the average annual population growth factor in Germany, 1925-37. 


\section{The Baseline Case}

We need to specify the initial conditions from which the economy starts, the public's expectations of future fiscal policy, productivity, and real wages for the 1928-37 time period, and expectations for these variables after 1937. Since the initial conditions are to some extent determined by the public's expectations about the future, we start with a description of these long-run expectations.

\section{Long-Run Expectations}

We assume that long-run fiscal policy is determined by long-run government spending. By this we mean that in the long run, government spending on goods and services is a fixed ratio of GNP, $g / y=\omega^{*}$. Here an asterisk is used to denote the detrended steady-state value of the variable in question. Furthermore, transfers are such that the after-tax value is a fixed ratio of GNP, $s / y=\left(1+\tau^{e}\right) \sigma^{*}$. Finally, the long-run effective tax rate is such that the government budget constraint is satisfied, $\tau^{*}=\omega^{*}+\sigma^{*}$. These assumptions on long-run fiscal policy imply that the net-of-interest government budget is balanced in the long run. If we were to assume that at some point in time, the government uses a lump-sum tax to eliminate the outstanding government debt, it does not matter how the government finances any interim deficits, whether by lump-sum taxation or by issuing debt. We set $\omega^{*}=0.13$ and $\sigma^{*}=$ 0.10 , which are the average values in Germany for the period $1925-28 .{ }^{19} \mathrm{We}$ note that in the post-World War II German economy, the share of government spending in the 1950s was around 15 percent. Only in the 1970s did this share increase to 20 percent. Finally, we also assume that in the long run, productivity is on its trend $A^{*}=1$, and real wages are market clearing.

\section{Initial Conditions and Transition Expectations}

We assume that in 1928, TFP for the German economy is on its long-run trend path, and the public expects the economy to stay on this growth path so that $A_{t}^{\text {base }}=1$ for $t \geq 1928$. In 1928 the government spending share is also at its long-run value, but the effective tax rate is not (see Table 4). We assume that the public expects that from 1929 on, taxes will converge to their long-run value at a 10 percent annual rate. More generally, fiscal policy converges toward the long run according to

$$
\omega_{t+1}-\omega^{*}=0.9\left(\omega_{t}-\omega^{*}\right) \text {, and } \tau_{t+1}-\tau^{*}=0.9\left(\tau_{t}-\tau^{*}\right) .
$$

Given the assumptions on the long run and the transition toward it, we now determine the initial conditions in 1928. We set the 1928 capital stock such that we match the private investment-GNP ratio in 1928, which is 0.13 . 
This initial capital stock will be common to all our experiments. We note that the investment-GNP ratio is quite stable from 1925 to 1928; it varies between 0.12 and 0.13 . We also note that the initial capital stock is below its steady-state value. It would be of interest to account for this feature of the initial condition, especially since we observed in the previous section that the German economy was below its long-run trend path for most of the interwar period. ${ }^{20}$ For the purposes of this paper, however, we simply treat it as given. To complete the specification of our baseline case, we assume that real wages are market clearing from 1928 on.

The perfect foresight solution for the baseline specification involves a steady-state transition with relatively small changes to the variables we are interested in. In particular, it generates a time path for fiscal policy $g_{t}^{\text {base }}, \tau_{t}^{\text {base }}$, and real wages $w_{t}^{\text {base }}$ for $t \geq 1928$. In the following, we will study the response of the growth model when we make alternative assumptions for the path of exogenous variables based on the German economy during the period 1928-37. We will judge the success of our framework in terms of how well it can account for the following main features of the data: (a) employment and output collapse in the decline phase of the Depression, but by the end of the recovery period are near their previous peaks, (b) private consumption and investment both collapse in the decline phase, but only investment shows a full recovery afterward, and (c) real wages first rise during the decline phase and then fall in the recovery period.

\section{Findings}

In this section we use our framework to analyze the contributions of productivity, fiscal policy, and high real wages to the Depression in Germany. To build our understanding of the effects at work in the model, we first consider each factor in isolation. After this, we combine the factors in the same model to assess their overall contribution to the decline and recovery.

\section{The Role of Productivity}

In the Depression, detrended TFP falls by roughly 13 percent from the peak in 1928 to the trough in 1932, and then recovers such that it exceeds its 1928 value by 16 percent (see Table 1). The usual caveats about identifying the Solow residual with exogenous productivity changes apply; in particular, the decline of TFP may reflect unmeasured changes in factor utilization. Nevertheless, productivity changes are a potential explanation for the Depression, and it is interesting to evaluate the contribution of productivity changes to these two phases.

In this experiment, we isolate the effect of TFP changes. We assume that real wages are market clearing, and we keep fiscal policy fixed at baseline 
values, that is, $g_{t}=g_{t}^{\text {base }}$ and $\tau_{t}=\tau_{t}^{\text {base }}$, for $t \geq 1929$. We assume that productivity trend deviations are given by

$$
\begin{aligned}
& \log \left(A_{t}\right)=\log \left(A_{t}^{a}\right)-\log \left(A_{1928}^{a}\right) \text { for } t=1929, \ldots, 1937, \text { and } \\
& \log \left(A_{t}\right)=0.9 \log \left(A_{t-1}\right) \text { for } t \geq 1938,
\end{aligned}
$$

where $A_{t}^{a}$ denotes the productivity trend deviation for Germany in the years 1928-37. For the years after 1937, we assume that productivity trend deviations converge to their steady state at a 10 percent annual rate.

The outcome of this experiment is shown in Figure 4. In this figure and the other figures describing model experiments discussed below, the solid lines denote model predictions and the dashed lines are actual data for Germany taken from Tables 1 and 3. This case is qualitatively quite successful at replicating the patterns of hours, output, investment, and consumption during the Depression, but it fails on the real wage behavior. Output falls by about 20 percent, about two-thirds of the actual drop. ${ }^{21}$ Hours fall by about 10 percent, a bit less than half the amount in the data. Investment falls dramatically in the model, much as it does in the data. However, the response is much more dramatic in the model as the nonnegativity constraint on investment becomes binding for four years. Consumption falls 6 percent by 1932, about a quarter of the actual decline. Some of the consumption decline can be attributed to the binding nonnegativity constraint on investment. Obviously, real wages have to decline for this experiment, and they fall by about 11 percent, completely at variance with the data. For the recovery phase, the main drawback of this experiment is that the recovery is too strong; this applies especially to employment and consumption. By a "too strong" recovery, we mean that the model predicts all variables to be well above trend at the end of the recovery phase, whereas this is certainly not true for the German economy in 1937.

We conclude that the productivity changes that occurred during the 1928-37 period, if they are assumed to be entirely exogenous, can account for a substantial portion of the Depression in terms of output, but do less well in explaining how hours, consumption, and investment behaved.

\section{The Role of Fiscal Policy}

We now study the joint effects of the tax and spending policies under the assumption that government policy after 1932 was not foreseen. This assumption prevents agents in the growth model from adapting their choices long before any change in policy actually occurs and is important for the results obtained. We discuss below where it makes a difference. This experiment helps address two questions. First, to what extent did the policy of auster- 
Figure 4. Effects of Decline in TFP
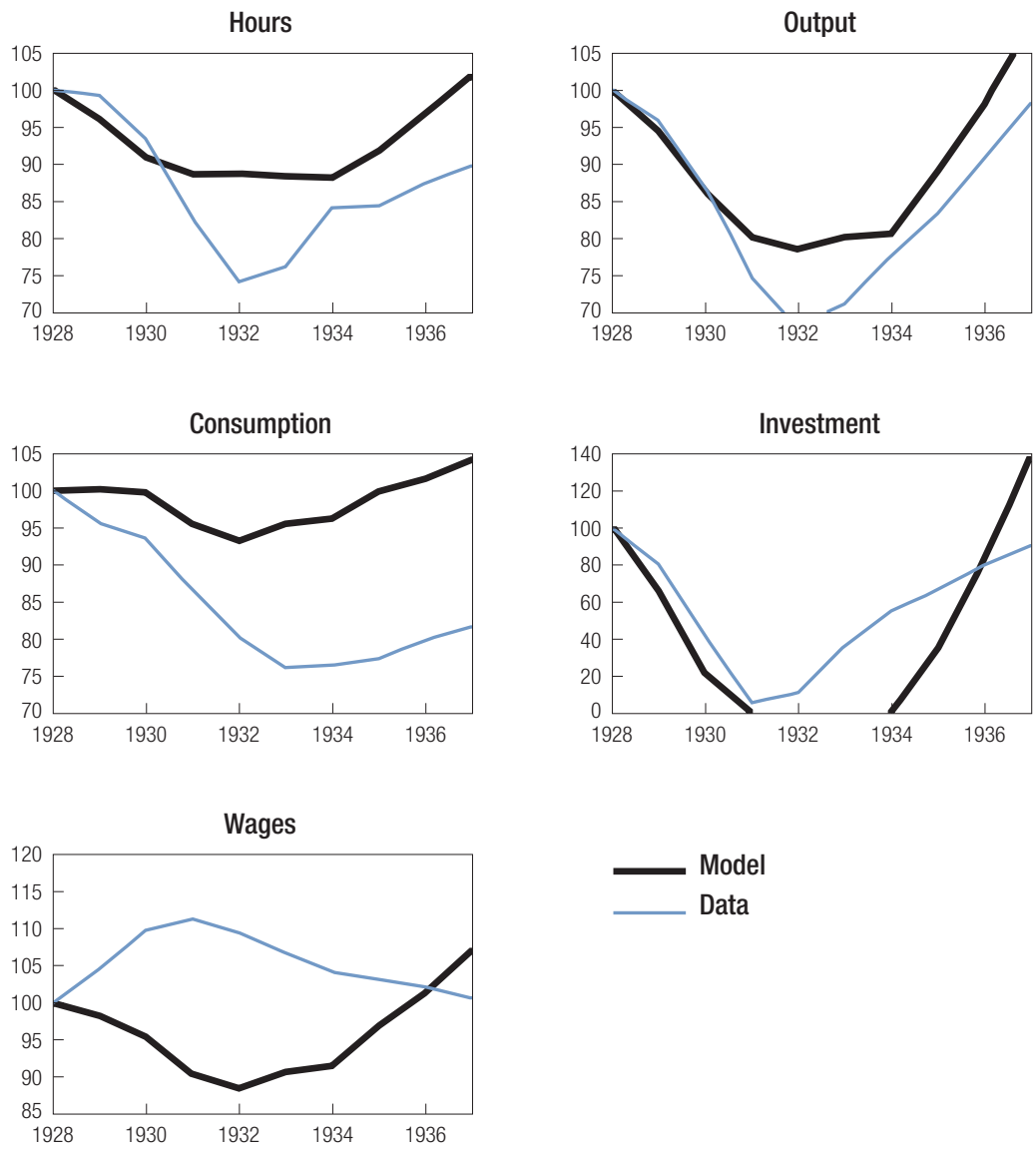

ity (here, mostly increases in tax rates) contribute to the decline phase of the Depression? Second, what was the contribution to the recovery of the dramatic increase in government spending after 1932?

In this experiment, we isolate the impact of changes in effective tax rates and government spending. We assume that real wages are market clearing and productivity is on trend, $A_{t}=1$ for $t \geq 1929$. We assume that actual fiscal policy is as in Germany 1928-37,

$$
g_{t}=\left(g_{t}^{a} / g_{1928}^{a}\right) g_{1928}^{\text {base }} \text { and } \tau_{t}=\tau_{t}^{a} \text { for } t=1929, \ldots, 1937 \text {, }
$$

where $g^{a}$ is total government spending from Table 3 and $\tau^{a}$ is the effective 
tax rate from Table 4. For $t>1937$, fiscal policy is determined by (2). We assume that before 1933 the public does not anticipate the big increase in government spending from 1933 on. In particular, for the years 1929-32, we assume that the public's expectations about government spending and tax rates $\bar{g}$ and $\bar{\tau}$ are correct only up to 1932 ,

$$
\bar{g}_{t}^{29}=g_{t} \text { and } \bar{\tau}_{t}^{29}=\tau_{t} \text { for } t=1929, \ldots, 1932 .
$$

The public mistakenly anticipates a return to long-run fiscal policy from 1932 on, according to (2). From the year 1933 on, we again assume perfect foresight on the part of the public:

$$
\bar{g}_{t}^{33}=g_{t} \text { and } \bar{\tau}_{t}^{33}=\tau_{t} \text { for } t \geq 1933 .
$$

The results of this experiment are shown in Figure 5. Since the regime shift in 1933 is unanticipated before then, the main impact of fiscal policy in the Depression period is through the increase in the effective tax rate. This depresses employment by about 7 percent, output by 5 percent, and investment by 30 percent. Consumption is essentially unchanged. Since the fall in employment is large relative to the decline in capital, real wages rise somewhat, although not as much as in the data. ${ }^{22}$ When 1933 arrives, the effects of fiscal policy are dominated by the large wealth effect associated with the massive increase in government spending. Taxes do not change much after 1932 and so have little additional impact over this period. The negative wealth effect causes a rebound in employment and investment, and consequently output as well. Since households feel poorer with the larger fiscal burden, consumption falls immediately in 1933 by about 5 percent, after which it stagnates. The rapid recovery of employment translates into a fall in real wages in the early stages of the recovery. If the Nazi regime were anticipated, that is, if the entire path of taxes and spending were foreseen as of 1928, we would then see very little of a decline or recovery in the model. This is because the wealth effect of higher spending would occur immediately and largely offset the depressing effect of the high taxes.

We conclude that the impact of fiscal policy when the Nazi regime's fiscal policy is unanticipated can account for roughly a quarter of the decline in hours and private expenditures in the Depression, due essentially to the higher taxes. The unanticipated large increase in government consumption after 1932 then explains about a third of the magnitude of the recovery phase. However, this view of fiscal policy implies a much-too-rapid recovery, that is, the model predicts a recovery within a year rather than over the five years observed in the German economy. 
Figure 5. Effects of unanticipated change in fiscal policy
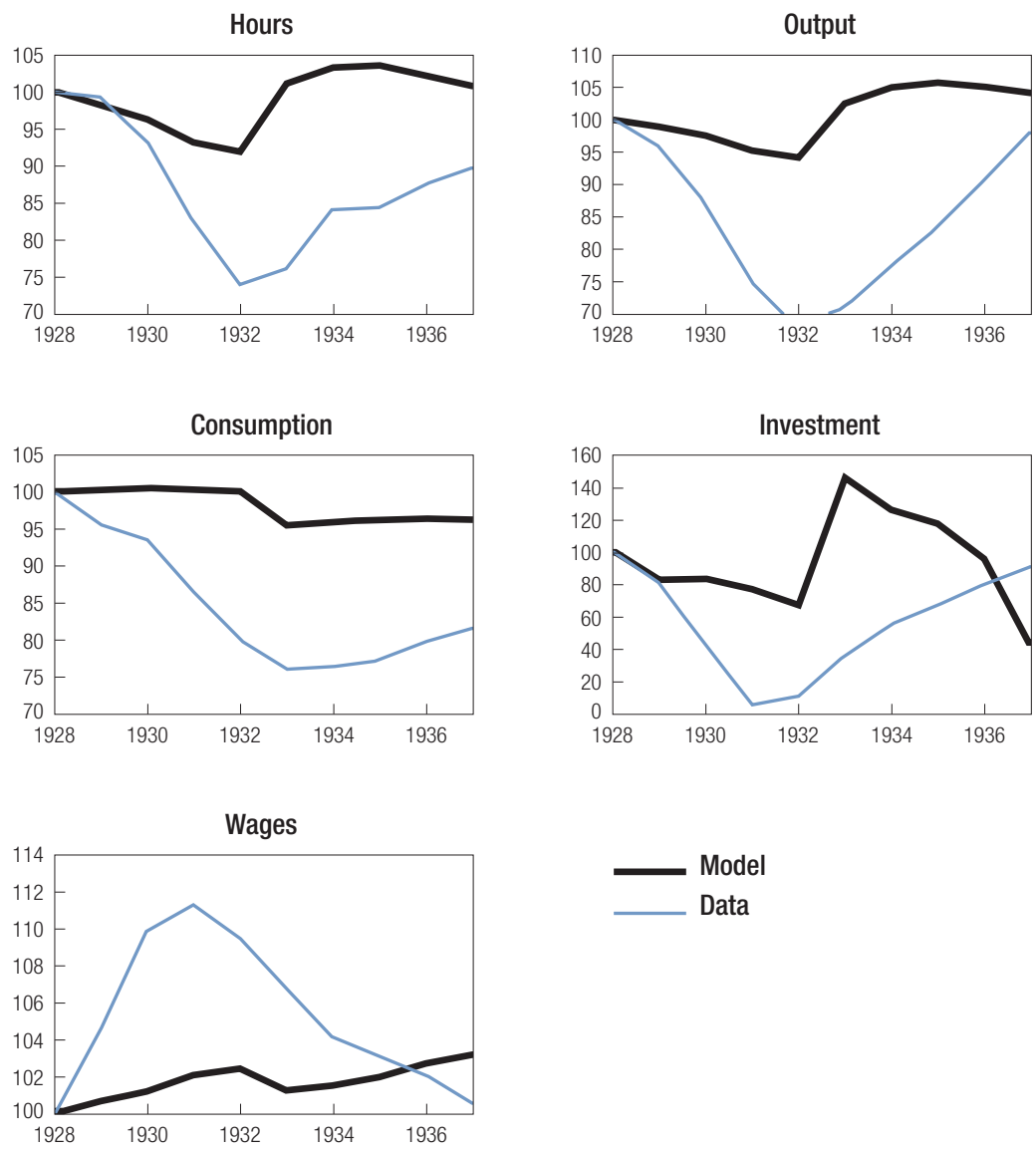

\section{The Role of "Too High" Real Wages}

Our observations on wage determination in the labor market suggest that due to collective bargaining arrangements, real wages were "too high" to clear the labor market. The evidence on industry nominal wages displayed in Figure 3 also suggests that the wage movements across industries were quite similar. Because real wages increase in all industries while aggregate labor productivity declines, we believe it is reasonable to study the question of "too high" real wages in the one-sector growth model.

In this experiment, we isolate the effect of an exogenous change in real wages. We keep fiscal policy fixed at baseline values, that is, $g_{t}=g_{t}^{\text {base }}$ and 
$\tau_{t}=\tau_{t}^{\text {base }}$, for $t \geq 1929$, and we assume that productivity is on trend, $A_{t}=1$ for $t \geq 1929$. For the years 1929-37, we assume that wages follow the actual time path for real wages in Germany, $w^{a}$, from Table 1. Employment is governed by labor demand subject to the constraint that workers are willing to work at the going wage. For $t=1929, \ldots, 1937$,

$$
\begin{aligned}
w_{t} & =\left(w_{t}^{a} / w_{1928}^{a}\right) w_{1928}^{\text {base }}, \\
w_{t} & =A_{t} \gamma^{(1-\alpha) t}(1-\alpha)\left(k_{t} / n_{t}\right)^{\alpha}, \\
\eta /\left(1-n_{t}\right) & \leq\left(1-\tau_{t}\right) w_{t} / c_{t} .
\end{aligned}
$$

After 1937, real wages are assumed to be market clearing again.

Recall that real wages rise until 1931, after which they fall back slowly to their 1928 level. When we take this path of wages as given, the model confirms that real wages are indeed too high for labor market clearing. The results shown in Figure 6 are quite dramatic. By 1932, output falls by about 25 percent, employment (hours) falls by 35 percent, consumption falls by 10 percent, and investment falls to zero. However, even though real wages decline substantially after 1931, the model generates only a small recovery in these variables, with the possible exception of hours. Interestingly, while consumption recovers somewhat, it remains about 5 percent below trend in the recovery phase, roughly a quarter of the decline in consumption in the data. The main drawback of this experiment, then, is that it fails to deliver a strong recovery.

\section{Combining the Effects of Changes in Productivity, Fiscal Policy, and Real Wages}

The previous results suggest that all three of these factors-productivity, fiscal policy, and high real wages - play quantitatively important roles in at least one phase of the Depression. However, these results could be misleading, since they involve analyzing each factor in isolation from the others. In this section we consider the implications of combining the factors in the same model.

First, consider the experiment where we combine the effects of changes in real wages and fiscal policy in the same model. Combining our previously stated assumptions for fiscal policy and for real wages, we get the results displayed in Figure 7. This experiment yields paths for output and employment that closely track the paths in the data, except that the hours path falls a little too fast in the decline. Consumption falls by about half the amount 
Figure 6. Effects of high real wages
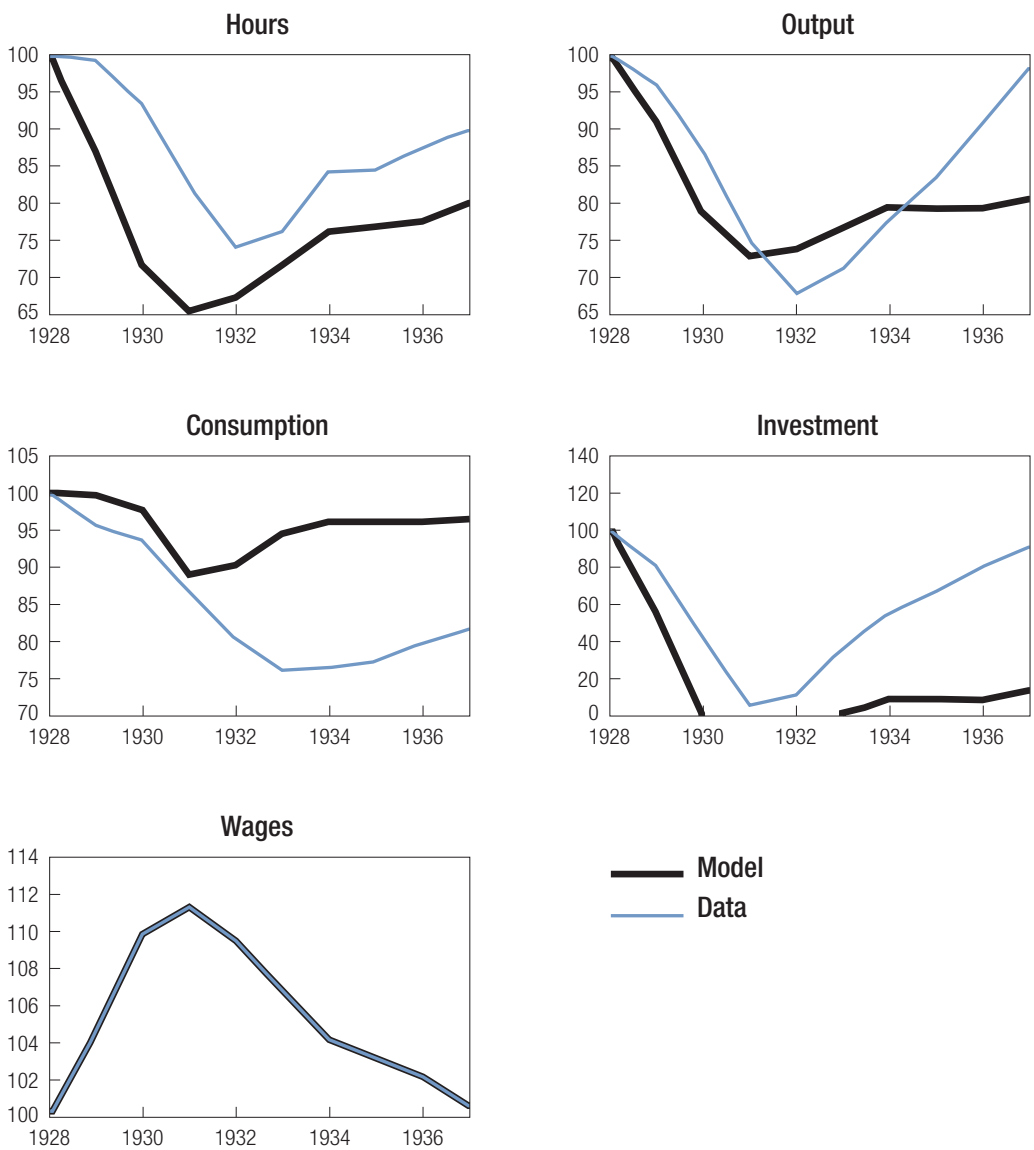

observed in the data, and investment falls by far too much. In the recovery phase, the main success of this experiment is that consumption continues to remain near its 1933 value, as in the data. The main failure here is that the recovery in investment is too weak.

We now add changes in TFP to the experiment so all three factors are at work in the model. This experiment adds the assumptions for productivity to those for the previous experiment. Figure 8 summarizes our findings. The combined effects of the three factors have a dramatic impact in the model. The model now has a sharp and strong decline and robust recovery in hours, employment, consumption, and investment. The main problem from an empirical standpoint are the magnitudes of the changes in these variables. 
Figure 7. Combined effects of fiscal policy and high real wages
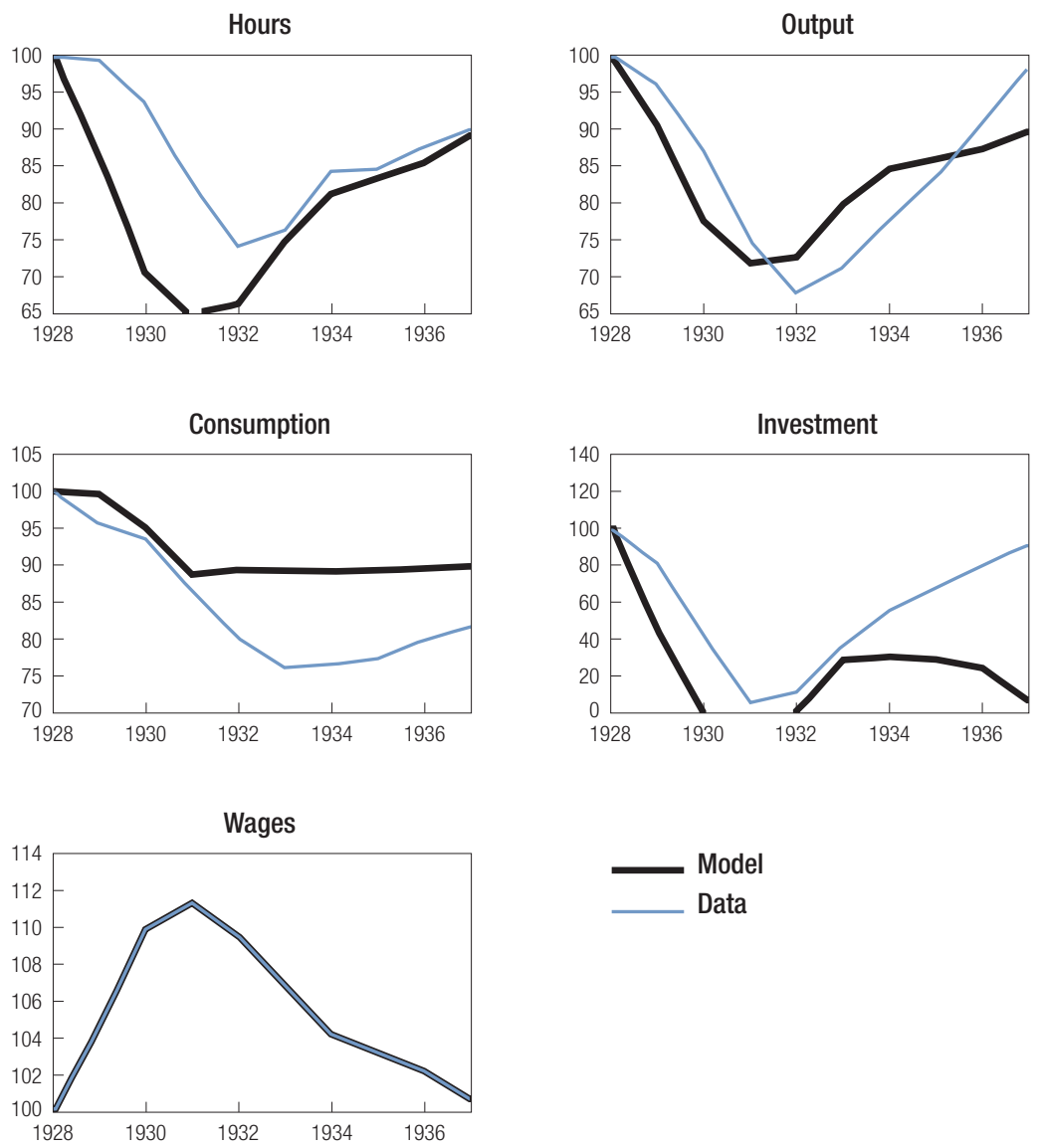

Output and hours fall by about 60 percent. Consumption falls by more than 50 percent and investment collapses completely.

\section{Conclusions}

Taken together, we view these results as establishing that the changes in real wages, productivity, and fiscal policy observed during the Depression in Germany account for much of the observed macroeconomic dynamics. We think that much of the decline in productivity was endogenous, indicating that the dramatic movements in the experiment that combines all three factors are overstated. We conjecture that incorporating variable factor utilization 
Figure 8. Combined effects of fiscal policy, high real wages, and TFP decline
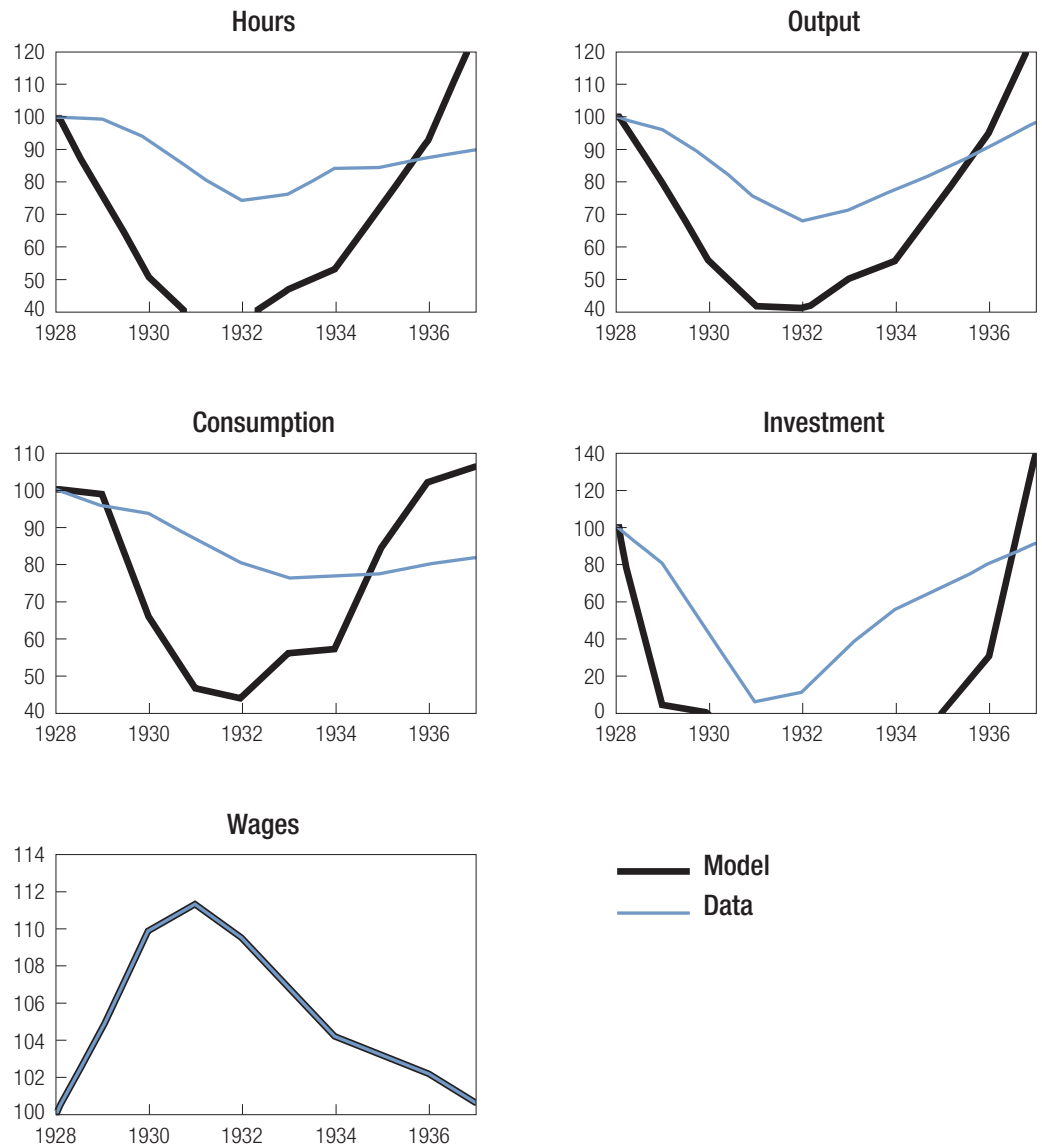

into the model, therefore endogenizing some of the decline in productivity, would lead to results somewhere in between the experiment that combines real wages and fiscal policy and the experiment that combines all three factors. If so, the combination of real wages and fiscal policy would essentially explain the entire Depression in real per capita GNP. 


\section{Appendix}

The national income accounts data (NIA) for Germany from 1925 to 1937 are from Ritschl 2002b. On the expenditure side they include GNP, private consumption, private fixed investment in equipment and structures and inventory investment, exports and imports, and government purchases of goods and services. Government spending does not include investment by the post office, the national railway, nor government-financed residential investment. These investments are included in private investment spending. On the income side, the NIA series include indirect taxes, subsidies, depreciation, and net national income at factor cost. Real (that is, constant) mark series are in 1913 prices. The data for the calculation of government's share in GNP and implicit tax rates are also from Ritschl 2002b. We use series on direct and indirect taxes, transfer payments, subsidies, and contributions to social security and unemployment insurance. The population series and the long-run GNP series 1901-95 are from Ritschl and Spoerer 1997. The series are not adjusted for territorial changes. The standard source for German economic data is Hoffmann 1965. Ritschl $2002 \mathrm{~b}$ is a recent revision of the German NIA for the interwar period. In Fisher and Hornstein 2001 we discuss the differences between the two sources.

For the construction of the labor income share, we use data on wages and salaries, proprietors' income in forestry and agriculture, and proprietors' income in manufacturing and trades from Bry 1960,122. We also include employer contributions to social security from Ritschl $2002 \mathrm{~b}$ in labor income. We assume that 90 percent of proprietors' income in forestry and agriculture is labor income. We assume that in trade and industry, the share of labor income in proprietors' income is the same as the labor income share for the economy as a whole. We calculate the share of labor income in GNP net of indirect taxes minus transfers.

Our measure of the capital stock includes private capital and some government capital, such as government-provided housing, the post office, and the national railway. Our capital stock measure does not include infrastructure capital derived from government investment in buildings and works (including roads). We construct capital stocks based on the perpetual inventory method with geometric depreciation. Gehrig (1961) argues that the annual geometric depreciation rate for structures is 0.32 percent. We estimate the annual geometric depreciation for equipment to be 3.16 percent based on Gehrig's series for equipment capital and investment. We then use these depreciation rates, Ritschl's (2002b) series for private investment on equipment and structures, and Gehrig's estimates of the capital stock in 1929, in order to construct capital stock series for equipment and structures. Since Gehrig's 1929 capital stock estimate for structures includes public capital, we adjust his estimate based on Hoffmann's (1965) estimate of public capital in 1929. Total capital is the sum of equipment and structures.

Our series on aggregate and industry employment and nominal wages are from Lölhöffel 1974. Wages are broadly defined and include payments in kind, employer 
contributions to social security and unemployment insurance, and payroll tax contributions. Employment is total hours worked. The quality of data is very uneven across industries and for some industries relies heavily on interpolation. The data for manufacturing appear to be the most reliable ones.

The cost of living price index and the wholesale price index for finished manufactures are from Bry 1960, 255. The implicit GNP deflator is calculated from Ritschl $2002 \mathrm{~b}$. The series for M1 includes currency in circulation plus demand and time deposits held by the nonbank public and is from Deutsche Bundesbank 1976, 4, Table 1.01.

We use annual estimates of the population 16 and over, series A39, from U.S. Department of Commerce 1975. Output is GNP in billions of 1987 dollars, Table 1.1, line 1, from U.S. Department of Commerce 1993.

\section{Notes}

Reprinted from Review of Economic Dynamics, Vol. 5, Jonas D. M. Fisher and Andreas Hornstein, "The Role of Real Wages, Productivity, and Fiscal Policy in Germany's Great Depression 1928-1937," pages 100-127, copyright 2002, with permission from Elsevier.

The views expressed herein are those of the authors and not necessarily those of the Federal Reserve Bank of Chicago, the Federal Reserve Bank of Richmond, or the Federal Reserve System.

We thank Ed Prescott for encouraging this line of research and for many helpful comments. Thanks also to Albrecht Ritschl for various discussions and for sharing his data with us. Finally, we thank participants at the "Great Depressions of the Twentieth Century" conference, and seminar participants at the University of Rochester, the University of Pennsylvania, and Humboldt Universität, Berlin, for helpful comments.

1. Unless otherwise noted, all variables are in real terms, that is, constant prices.

2. Attempts have been made to construct separate estimates of Austrian and German GNP, e.g., Maddison 1991. We are not convinced that these numbers are reliable.

3. A number of economic historians have therefore suggested that the causes of the Depression in Germany lie in the years before 1928. For example, Borchardt (1979) argues that developments in the labor market in the mid-1920s contributed to the Depression in Germany. We do not pursue this argument here, and take the state of the economy in 1928 as given.

4. We believe that our estimates of the employment decline in Germany are conservative. In Fisher and Hornstein 2001 we discuss alternative employment measures for Germany that indicate that employment falls even more.

5. We calculate TFP as the Solow residual from our measure of output, and our input measures capital and labor, assuming a constant labor income share. We use our estimate of the average labor income share for the German economy 1925-37, described in the appendix.

6. Real wages are nominal wages from Lölhöffel 1974 deflated with the wholesale price index of finished manufactures from Bry 1960. In Fisher and Hornstein 2001 we discuss alternative measures of nominal wages. The deflator appears to be the standard one used in studies of the German economy of the 1920s. The deflator is also the closest we can get to a product wage for manufacturing. 
7. Our analysis continues to address monetary issues indirectly, through the impact of general price movements on real wages.

8. Our description of the German labor market relies heavily on Bry 1960 and James 1986.

9. The collective bargaining system extended arrangements from the war economy. Another element of the Stinnes-Legien agreement was the introduction of the eight-hour workday/fortyeight-hour workweek. This feature survived until 1923.

10. The following estimates are based on Bry 1960, 24-45.

11. The regime also used the system of agricultural price controls to support the wage controls. There is some doubt as to how effective all of these interventions in the labor market actually were (James 1986).

12. In Fisher and Hornstein 2001 we display separate time series for government consumption and investment.

13. In Fisher and Hornstein 2001 we display separate time series for fixed investment and inventory investment. In our data set, Ritschl 2002b, inventory investment is not deflated. Given the substantial deflation over this time period, the nominal inventory decline understates the real decline of inventories.

14. This short sketch of public finances relies heavily on James 1986 and Overy 1982. Unless otherwise noted, numbers quoted are from James 1986.

15. The constructed tax rates are consistent with the tax rates in the model described below.

16. A factor that plays an important role for the politics of post-World War I Germany, but which we abstract from in our analysis, are the reparation payments imposed in the Versailles Treaty. These reparation payments contributed to the budgetary problems of the German government in the late 1920s. From 1925 to 1929 the share of reparation payments in total government spending increased from 6.5 percent to 9.7 percent, and in 1929, reparation payments were 2.6 percent of nominal GNP (Ritschl 1999). The Brüning government's foreign policy objective was the elimination of reparation payments, and it was successful at that. Over the course of the Depression, the share of reparation payments in nominal GNP declined to less than 1 percent in 1932, when reparation payments were canceled altogether at the Lausanne conference. We anticipate that including these effects in our analysis of the growth model would have a small positive wealth effect in the Depression, which would contribute somewhat to the observed downturn in labor input, output and investment, but would increase consumption.

17. The more radical economic measures of the Hitler regime were the dissolution of the unions, the remains of which were absorbed into the Nazi-controlled German Labor Front, and a drastic enforcement of the system of price and wage controls already started by the Brüning government. The use of price controls led to significant quality reductions, especially for consumer goods. The turning point toward a state-controlled economy was the Four Year Plan of 1936-37, which reallocated resources from private industry to government-controlled steelworks.

18. See the appendix for the construction of the labor income share and the depreciation rate.

19. Essentially we assume that private agents perceive the fiscal policy of the Nazi regime as temporary rather than permanent. To see how robust our results are, we have replicated the following experiments assuming a larger long-run government share, $\omega^{*}=0.32, \sigma^{*}=0.08$, and $\tau^{*}=0.4$. Our main conclusions are not affected by this alternative parameterization. 
20. If we draw a linear trend line in Figure 2, we see that in 1928, GNP was about 20 percent below trend. We can attribute this below-par performance to a temporarily low productivity level and an off-steady-state capital stock. With these assumptions we set the initial productivity trend deviation and the capital stock in 1928, such that we match the private investment-GNP ratio and the output trend deviation in 1928 . We also assume that productivity returns to trend according to (3). This choice of initial conditions does not affect the results from our experiments very much.

21. This is consistent with the behavior of U.S. output predicted by the stochastic growth model analyzed in Cole and Ohanian 1999.

22. The magnitude of the employment response depends on the relatively high labor supply elasticity implied by our parameterization. For a discussion of the quantitative importance of our assumption in the context of the post-World War II U.S. economy, see Burnside, Eichenbaum, and Fisher 2004.

\section{References}

Borchardt, Knut. 1979. Zwangslagen und Handlungsspielräume in der großen Wirtschaftskrise der frühen dreißiger Jahre: Zur Revision des überlieferten Geschichtsbildes. In Jahrbuch der Bayerischen Akademie der Wissenschaften, 85-132. Reprinted as Constraints and room for manoeuvre in the Great Depression of the early thirties: Towards a revision of the received historical picture. In Perspectives on modern German economic history and policy, ed. K. Borchardt, 143-60. Trans. Peter Lambert. Cambridge: Cambridge University Press, 1991.

Bry, Gerhard. 1960. Wages in Germany 1871-1945. Princeton, NJ: Princeton University Press.

Burnside, Craig; Martin Eichenbaum; and Jonas Fisher. 2004. Fiscal shocks and their consequences. Journal of Economic Theory 115 (March): 89-117.

Cole, Harold L., and Lee E. Ohanian. 1999. The Great Depression in the United States from a neoclassical perspective. Federal Reserve Bank of Minneapolis Quarterly Review 23 (Winter): 2-24.

Deutsche Bundesbank. 1976. Deutsches Geld-und Bankwesen in Zahlen, 1876-1975. Frankfurt am Main: Verlag Fritz Knapp.

Eichengreen, Barry. 1992. Golden fetters: The gold standard and the Great Depression, 1919 to 1939. Oxford: Oxford University Press.

Fisher, Jonas, and Andreas Hornstein. 2001. The role of real wages, productivity, and fiscal policy in Germany's Great Depression 1928-37. Federal Reserve Bank of Richmond Working Paper 01-07.

Gehrig, G. 1961. Eine Zeitreihe für den Sachkapitalbestand (1925 bis 1938 und 1950 bis 1957). IFO-Studien 7: 7-60.

Hoffmann, Walther G. (with F. Grumbach and H. Hesse). 1965. Das Wachstum der Deutschen Wirtschaft seit der Mitte des 19 Jahrhunderts. Heidelberg: Springer Verlag.

James, Harold. 1986. The German slump: Politics and economics, 1924-1936. Oxford: Oxford University Press. 
Lölhöffel, M. V. 1974. Zeitreihen für den Arbeitsmarkt - Lohnsatz, Beschäftigungsf älle, Arbeitskosten und Arbeitsstunden (1925 bis 1938 und 1950 bis 1967). IFO-Studien 20:33-150.

Maddison, Angus. 1991. Dynamic forces in capitalist development: A long-run comparative view. Oxford: Oxford University Press.

Overy, Roy J. 1982. The Nazi economic recovery, 1932-1938. London: Macmillan.

Ritschl, Albrecht. 1999. Les réparations allemandes, 1920-1933: Une controverse revue par la théorie des jeux. Economie Internationale 78:129-54. -2002a. Deficit spending in the Nazi recovery: A critical reassessment. Journal of the Japanese and International Economy 16:559-82.

2002b. Deutschlands Krise und Konjunktur: Binnenkonjunktur, Auslandsverschuldung und Reparationsproblem zwischen Dawes-Plan und Transfersperre, 1924-1934 (The German Business Cycle, 1924-1934: Domestic Activity, Foreign Debt, and Reparations from the Dawes Plan to the Debt Default) (in German). Berlin: Akademie-Verlag.

Ritschl, Albrecht, and Mark Spoerer. 1997. Das Bruttosozialprodukt in Deutschland nach den amtlichen Volkseinkommens- und Sozialproduktsstatistiken, 1901-1995 (A series of gross national product in Germany based on the official national income and product statistics, 1901-1995). Jahrbuch fuer Wirtschaftsgeschichte (part 2): 11-37.

U.S. Department of Commerce. Bureau of Economic Analysis. 1993. The national income and product accounts of the United States. Vol. 1, 1929-58.

U.S. Department of Commerce. Bureau of the Census. 1975. Historical statistics of the United States: Colonial times to 1970. Part 1. 